\title{
The South African Species of Lagarosiphon
}

\author{
by
}

\section{A. A. Obermeyer}

An examination of the southern African species of this genus revealed that each had a typical leaf-structure, a useful character since plants are often sterile.

Very little was known of the life-history of this genus until Wager's work appeared in 1928.* Afterwards Dr. M. Ernst-Schwarzenbach also studied the flower-biology of L. muscoides. ${ }^{+}$Wager observed 2 species common on the Highveld, L. muscoides and L. major. As the other three South African species appear closely related, it is likely that in general their behaviour will be similar.

Examining dried material, especially of such small dimensions, is not very satisfactory. Living plants must be studied in the manner in which it was done by Wager, to give us a more complete picture of their life-history. As so little was known about these species when Wright made his compilation for the Flora of Tropical Africa, his treatment of them is unsatisfactory. Some are no better than generic descriptions and without having seen the types, it is impossible to recognize the plants concerned.

Lagarosiphon Harv. in Hook., Journ. Bot. Lond. 4: 230 (1841). Benth. \& Hook. f., Gen. Pl. iii: 450 (1883). Phill., Gen. ed. 2: 58 (1951).

Submerged, dioecious, rooted herbs from a perennial rhizome with long terete leafy stems; branches arising from inside a spathe next to a flower. Leaves widely spaced below, dense above, alternate, subopposite or whorled; with 2 minute narrowly ovoid intravaginal squamulae: margin toothed (each tooth unicellular); lamina with variation in cell structure. Male inflorescence axillary; spathes 2 united bracts, obovate or ovate to lanceolate, compressed or cup-shaped, dentate; the axis (rudimentary inflorescence) producing numerous pedicellate flowers (up to 50 were counted in $L$. major) consecutively; the buds (in South African species) become detached and rise to the surface before anthesis where they expand; perianth in 2 whorls of 3 segments each (the outer segments slightly narrower), recurving suddenly to form a bell-shaped structure that floats on the water; stamens 3, the filaments when expanded situated parallel to the water-surface with the anthers at right angles to them; each pollen-sac containing 4 tetrads, grains large; staminodes 3, longer than the stamens, papillate and usually coloured above, joined at the top, acting as a sail. Female inflorescence axillary; spathes 2, fused, narrowly oblong, ovoid or cylindrical, entire or toothed, containing 1-2-3 flowers (when the capsule develops the inner spathe, which is usually larger, splits centrally along the midrib); perianth-tube exserted laterally near the apex of the spathes, lengthening and giving off gas-bubbles continuously inside the delicate tube to buoy it up so that it will reach the surface (ultimate length of flower depends on the species: in $L$. muscoides up to $25 \mathrm{~cm}$, in $L$. major $15 \mathrm{~cm}$; if it has not reached the surface by then, it will die); limb 6-lobed; staminodes 3, small, filiform; ovary 1-locular with 3 parietal placentas; styles 3 , adnate to the perianth-tube, each divided above into 2 long, papillate, often brightly coloured stigmas; ovules 6-30, orthotropous, funicle short or long, straight or bent. Capsule ovoid or cylindrical, attenuate at the apex into a beak (the persistent base cf the perianth), protruding from torn spathevalves; becoming mucilaginous and bursting irregularly and so dispersing the seeds;

* Wager, V. A. in Trans. Roy. Soc. S.A. 16: 191-204 (1928).

† Ernst-Schwarzenbach, M. in Ber. Schweiz. Bot. Ges. 5: 56-58 (1945). 
seeds cylindrical, with a short stipe at the base, pointed at the apex, size varying with each species, closely ribbed or honeycombed, buoyant at first, sinking later (viable only after about 6 months in L. muscoides and L. major, unknown in other species).

About 16 species found in Africa, 2 endemic to Madagascar. L. major is reported as an adventive in Europe and New Zealand.

Leaves thin, transparent, $0.5-2 \mathrm{~mm}$ broad, cells usually longer than broad:

Leaves with a hyaline margin consisting of at least 3 layers of cells without chlorophyll 1. L. muscoides Leaves green to the margin, teeth on small excrescences:

Leaves in verticils of 6-8; central band usually narrow and the cells not much different

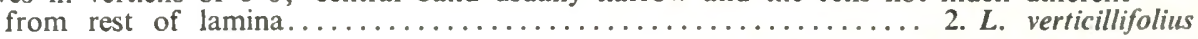

Leaves alternate or sometimes in verticils of $2-5$; central band usually wide, at least near the base, with the cells much larger and with transverse septa........... 3. L. crispus Leaves more solid, opaque, $2-3 \mathrm{~mm}$ broad, cells small, somewhat papillose-rhomboid:

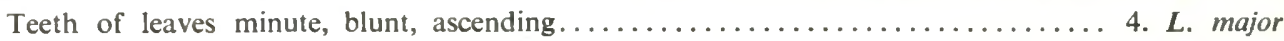

Teeth of leaves on triangular excrescences, sharp, patent................ 5. L. ilicifolius

1. L. muscoides Harv. in Hook. Journ. Bot. Lond. 4: 230, t. 22 (1841). Wright in F.T.A. 7: 3 (1897); F.C. 5, 3: 1 (1912). Marloth, Flora of S.A. 4: 15, fig. 6 t. 2 (1915). Wager in Trans. Roy. Soc. S.A. 16: 191 (1928). Ernst-Schwarzenbach in Ber. Schweiz. Bot. Ges. 55: 56 (1945). Syntypes: Cape, Albany, Zeyher ô, $q$ (TCD); without locality, Drege + (TCD).

Hydrilla dregeana, Presl, Bot. Bemerk. 112 (1844). Type: Cape, Port Elizabeth district, swamp near the mouth of the Swartkops River, Drege 2276c. H. muscoides Planch. in Ann. Sci. Nat. Sér. 3, Bot. 11: 79 (1849). Haloragea Drege, Zwei Pfl. Doc. 130 (1843). Fluvialea Drege, 1.c. 136, 140.

Stems $0 \cdot 5-2 \mathrm{~mm}$ in diam., usually weak. Leaves alternate, somewhat laxly spaced on the stems, spreading, soft, thin, transparent, light green, linear, average size 10 by $1.5 \mathrm{~mm}$, apex acute, margin with 3 rows of hyaline cells, teeth many, acicular, pointing upwards, leaf-tip with 2 slightly larger teeth, cells of lamina elongate-oblong, with 2-3 rows of cells on each side of midrib which are slightly ligher in colour, outer row with thickened cell walls. Male inflorescence: spathe-valves flat, obovate, about 4 by $2 \mathrm{~mm}$ with about 23 teeth on each side; with up to 40 flower-buds inside, flowers white to pink. Female inflorescence: spathe-valves, ovoid, about 4.5 by $1.5 \mathrm{~mm}$, with about 25 long, acute teeth on each side; perianth white, maximum length up to $25 \mathrm{~cm}$; ovary flask-shaped, stigmas purple, ovules about 12, funicles straight or bent in narrow ovaries. Capsule narrow-ovoid to tubular, about 5-10 mm long; about 9 seeds in each capsule, breaking away from the placenta and pushed upwards one behind the other, about $2-2 \cdot 5 \mathrm{~mm}$ long, surface honeycombed.

Widespread in the summer rainfall areas of southern Africa, from Uitenhage in the eastern Cape to Natal, Orange Free State, northern Cape, South West Africa, Bechuanaland, Transvaal, Southern Rhodesia, extending to tropical east Africa.

CAPE.--Port Elizabeth, Gamtoos River, Schlechter 6059. Albany: Collingham near Grahamstown, Dickens. Hay: Papkuil sloot, Wilman 1247. Barkly West: in vlei at Holpan, Acocks 2308.

Orange Free State.-Kroonstad: near convent, Pont 602. Fauresmith: near Luckhoff, farm Klein Gryskop, 445, Smith 499.

Basutoland.-Banen, boggy water of stream to Pela Tseon River, Jacot-Guillarmod 2066. Leribe: Makokoane, Dieterlen 1031.

Natal.-Bergville: Rustenberg Road from Bergville, Edwards 2409. 


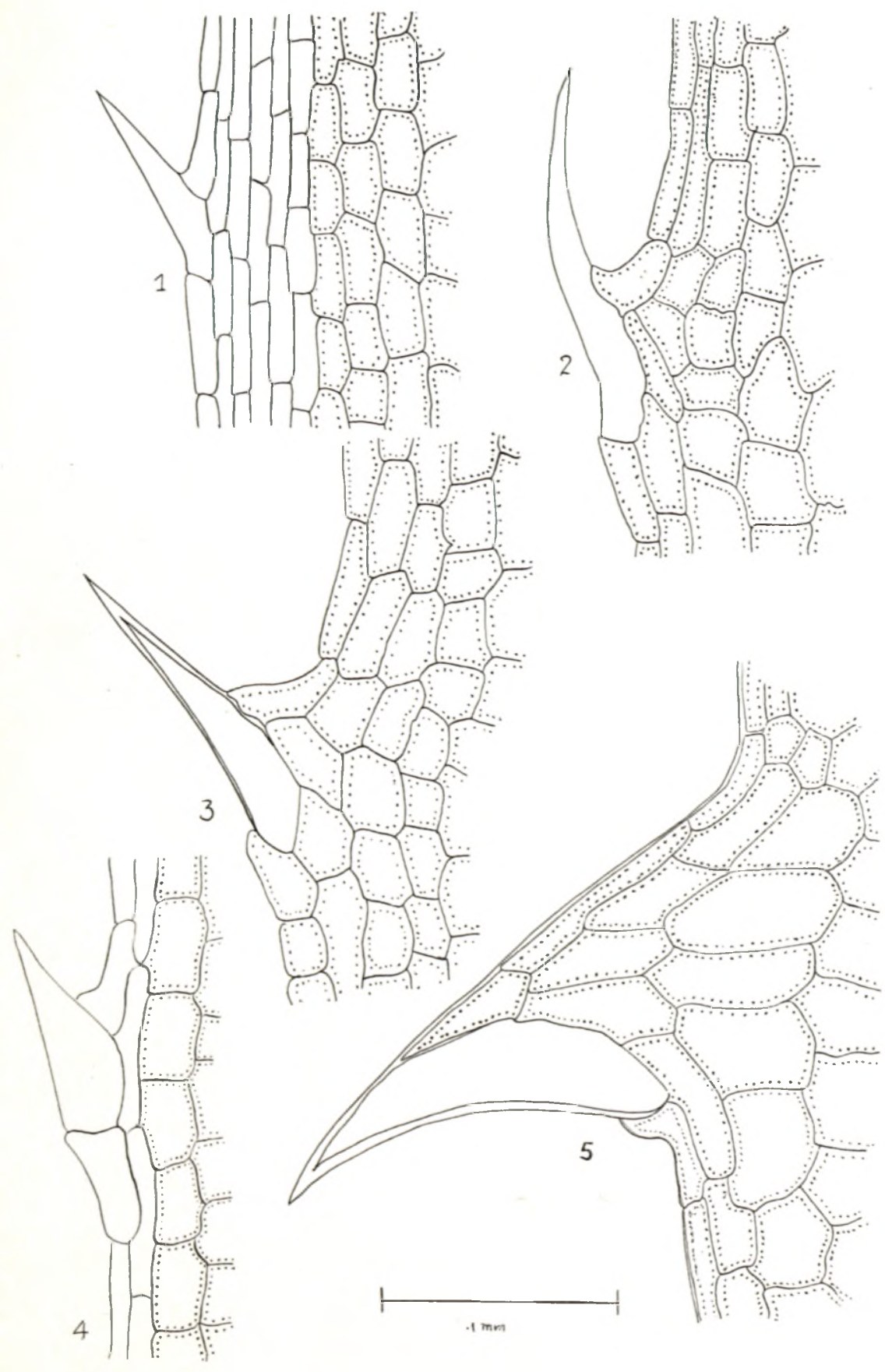

FIG. 1.-Leaf margins of Lagarosiphon species showing spines and location of chloroplasts (dotted lines). 1. L. muscoides Harv. (Burtt Davy, PRE 12792) Transvaal, Christiana. 2. L. verticillifolius Oberm. (Sim 436) Moçambique, Lourenço Marques. 3. L. crispus Rendle (Erens 351) Bechuanaland, Tsotsoroga Pan about $150 \mathrm{~m}$. North of Maun. 4. L. major (Ridley) Moss ex Wager (Cooper 17) Cape, Victoria East, Umdizine River. 5. L. ilicifolius Oberm. (Galpin 7027) Southern Rhodesia, Zambesi River above Victoria Falls. 
TransvaAl.-Christiana: Burtt Davy 12792. Potchefstroom: Witpoort, Louw 1708. Benoni: Moss 11175. Pretoria: Kaallaagte 5 miles E. of Hammanskraal, Mauve \& Schlieben 9599. Belfast: pan 5 miles W. of Belfast, Obermeyer in TRV 36067. Kruger National Park: Bobubu, van der Schijff 5671. Pietersburg: Blauwberg, Nacarene, Strey \& Schlieben 8579. Soutpansberg: Duwenhage's Pan, Schweickerdt \& Verdoorn 627.

SOUTH WEST AfRICA.-Gibeon: Haribes, Volk 12405. Rehoboth: Bullspoort, Strey 2118; Rodin 2940. Okahandja: Bradfield 390. Grootfontein: Kumkaus, Kinges 2836; Grosshuis, in vleiwater, Schoenfelder S648 \&; Dinter 7384 ㅇ.

Bechuanaland.--Northern part, Mumpswe Pan, 25 miles N.N.W. of mouth of Nata River, Drummond \& Seagrief 5165; 5166.

Southern Rhodesia.-Salisbury, 6 Mile Spruit, Wild 3799; 3800; 3803 (SRGH); Avondale, Eyles 5841 (SRGH). Wankie Game Reserve, 8 miles from Ngomo, Weir 9 (SRGH).

TAnganYIKA.-Mbulu: Mbulumbula, Greenway 6799 (SRGH).

The following specimens cannot be named satisfactorily:-

CAPE.-Komga: near Komga, Flanagan 1335.

NATAL.-Dundee: Tim Worthington Dam, Hammer. Estcourt: Tabamhlope Research Station, Little Bushmans River, West 900. Newcastle: west of Laingsnek-Quaggasnek Road, Edwards 2369.

TransvaAl.-Standerton: Farm Beginsel, Burtt Davy 2287. Potchefstroom: Frederikstad, Mooi River, Louw 1709.

In appearance these plants resemble an overgrown $L$. muscoides plant. Wager noted that he found this large form usually together with $L$. muscoides in Natal. There is only one fertile collection (Flanagan 1335). As L. muscoides and L. major are both recorded from these regions, it was thought that they could be hybrids but ErnstSchwarzenbach, who crossed these two taxa, found them to be incompatible [Oesterr. Bot. Zeitschr. 100: 420 (1953)].

\section{L. verticillifolius Oberm., sp. nov.}

Planta tenuis. Caulis ca $0 \cdot 5-1 \mathrm{~mm}$ diam. Folia 5-7 verticillata, verticillis ad apicem congestis; lamina pellucida patens linearis, margine chlorophyllacea dentibus multis brevibus acicularibus e excrescentibus triangularibus ortis, cellulis centralibus amplioribus parte media anguste formantis. Spatharum valvae, ô, lanceolatae paucidentatae apice acutae, $q$, ad basin ovoidea ad apicem tubulosae tantum pauci-dentatae; ovarium 9-12 ovulis funiculo recto brevi. Capsula ovoidea attenuata. Semina $1 \cdot 5 \mathrm{~mm}$ longa.

Type: Natal, Hlabisa, Hluhluwe Game Reserve, Ward 2551 q (PRE, holotype).

Stems $0.5-1 \mathrm{~mm}$ in diam., fairly firm, densely leafy. Leaves in verticils of 7 (sometimes 5) occasionally sub-whorled, closely spaced on the stems (internodes up to $2 \mathrm{~cm}$ below, 4-2 $\mathrm{mm}$ above), spreading, soft, thin, transparent, linear, average size 10 by $0.5 \mathrm{~mm}$, but occasionally up to $20 \mathrm{~mm}$; margin chlorophyllous, teeth many, short, acicular, pointing out- and upwards, emerging from a triangular excrescence; leaf-tip 1-2-toothed similar to the marginal teeth, with a few rows of cells beside the midrib that are slightly larger, lacunar, the outer row with thickened walls. Male inflorescence with the spathe-valves lanceolate, convex, about 2.5 by $1 \mathrm{~mm}$, pointed at the apex, with a few small marginal teeth. Female inflorescence with the spathevalves ovoid below, tubular above, apex bifid, occasionally with a few marginal teeth; perianth white; stigma-branches long, with large papillae; ovary with 9-12 ovules, 
funicle straight, shorter than ovule. Capsule ovoid 5 by $2 \mathrm{~mm}$, elongated at the apex; seeds $1.5 \mathrm{~mm}$ long, narrowly grooved and with some protrusions (glandular?). bique.

Recorded from Southern Rhodesia, eastern Transvaal, Zululand and Mozam-

Southern Rhodesia.-Nuanetsi, 30 miles S. of Chipinda Pools, Phipps 2909; Malangwe River, S.W. of Mateka Hills, Drummond 5627; 5628.

MozambiQue.-Lourenço Marques, Sim 436, Rogers 21378. Rikatla, Junod in TRV 25432.

TransvaAl.-Pilgrim's Rest: Kruger National Park, 19! miles N.E. of Skukuza, Codd 6069; Letaba: K.N.P., Shangoni, Mathlambanthlova Pan, van der Schijff 2857.

Natal.--Hlabisa: Hluhluwe Game Reserve, Ward 2518; 2549 ¡; 2551 f (PRE, holotype). Ubsmbo: Mkuzi Game Reserve, Tinley 443.

Easily distinguished by the many-leaved whorls.

3. L. crispus Rendle in J. Linn. Soc. Bot. 30: 381, pl. 31, fig. 8-17 (1895); F.T.A. 7: 4 (1897). Type: Tanganyika, between Uyui and coast, Taylor (BM, holo.).

L. tsotsorogensis Brem. \& Oberm. in Ann. Tvl. Mus. 16: 401 (1935). Type: Bechuanaland, Tsotsoroga Pan, van Son TRV 28853 (PRE, holo.).

Stems filiform, 1-2 $\mathrm{mm}$ in diam. Leaves alternate, sub-opposite to verticillate above, usually densely spaced on the stems, spreading, soft, thin, transparent, linear, average size 14 by $0.5 \mathrm{~mm}$, marginal cells chlorophyllous, the many, sharp curved teeth pointing upwards, situated on small, triangular excrescences; leaf-tips bi-dentate; central area narrow to very broad, consisting of larger lacunar cells without or with very little chlorophyll, usually with transverse septa, midrib distinct. Male inflorescence: spathe-valves cup-shaped, obovoid, about $2 \mathrm{~mm}$ long, acute at first becoming broad and gaping during anthesis, with about 8 teeth on each side. Female inflorescence: spathes forming a narrow ovoid tube $2.5 \mathrm{~mm}$ long, entire or with a few small teeth, apex entire at first, becoming bilobed; perianth white, limb about $2 \mathrm{~mm}$ in diam.; ovary with 24-30 ovules, funicles about as long as the ovules; stigmas with short papillae. Capsule ovoid, acuminate, about $3 \mathrm{~mm}$ long, many-seeded; seeds $1 \mathrm{~mm}$ long, turbinate, with raised ridges which have transverse septa (in the dried state).

Recorded from East Africa, Southern Rhodesia, Bechuanaland, South West Africa, eastern and northern Transvaal.

KenyA.--Northern Province, Sololo, Gillell 13683.

TANGANYIKA.-Kivingo, Greenu ay 1979.

Southern RhOdesia.--Urungwe, Zambesi Valley, Menswa Pan, Wild 4069; 17 miles E.S.E. of Chirundu Bridge, Drummond 5404 (SRGH). Lower Sabie, Wild 2318 (SRGH). Subungwe, Marawa road, Davies D1968 (SRGH).

TransvaAl.-Soutpansberg: Limpopo River, farm Weipe, in pan, Codd \& de Winter 348; Verdoorn 2273. Pilgrim's Rest: Leeupan near Tshokwane, vun der Schiiff 2766; 4198.

Bechuanaland.-Tsotsoroga Pan about 150 miles N. of Maun, Frens 351.

South WeSt Africa.--Caprivi Strip: Kabuta Village in Chobe River, Munro. Okavango: Niangana, Okavango River, Dinter 7246. Grootfontein: West of Andara, Merxniiiller 2096.

Characteristic of $I$. crispus Rendle are its small flowers (limb 1.5-2 $\mathrm{mm}$ in diam.), small, broadly ovoid capsules about $2.5 \mathrm{~mm}$ long and many seeds which are $1 \mathrm{~mm}$ long 
(ovary with 24-30 ovules). In the South African specimens the leaves show the characteristic lacunar broad central band with transverse septa at least in lower half. However, some specimens from tropical Africa have the leaves longer $(2 \mathrm{~cm}$ instead of 1$)$ and the band indistinct. Whether they belong to another species could not be decided here.

In van der Schijff 4198, three setaceous appendages were noticed at the base of the ovary similar to those seen in Schoenfelder 5648 (L. muscoides Harv.) from South West Africa. They may be the rudiments of aborted flowers. Rendle noted that he found no intrafoliar stipules. They were present in some specimens, but others appeared to be without them; they may be early deciduous; such delicate organs easily disintegrate during pressing and drying.

Sometimes the plants are much branched, foliose, with the leaves rather long $(2 \mathrm{~cm})$. This could be its habit when, through external circumstances, natural sexual reproduction is hampered. The species is apparently related to $L$. tenuis Rendle.

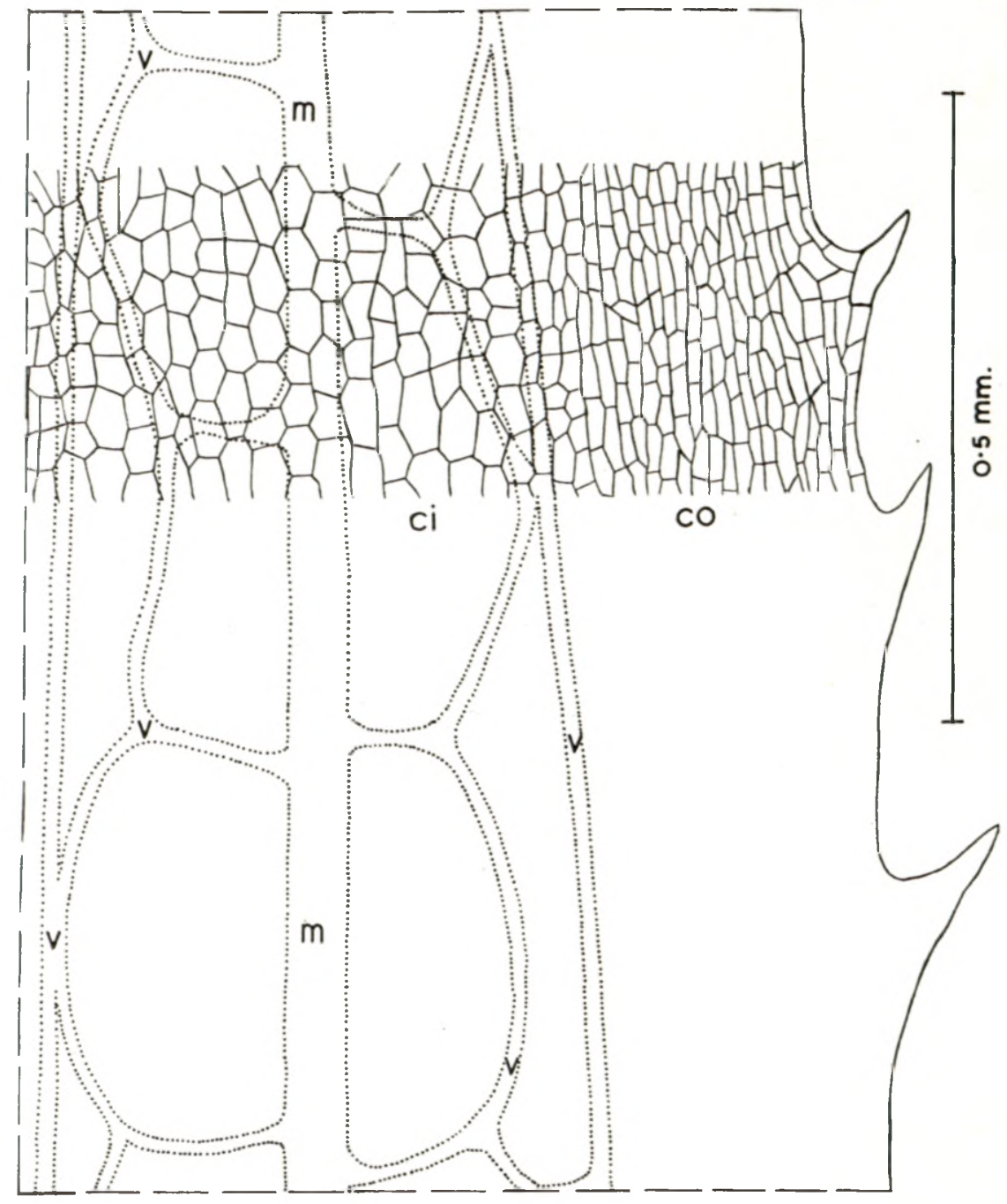

FIG. 2.-Lagarosiphon crispus Rendle. Part of leaf seen from above showing midrib ( $m$ ) and network of veinlets (v); ci, large central cells; co smaller outer cells (Erens 351). 
4. L. major (Ridley) Moss apud Wager in Trans. Roy. Soc. S.A. 16: 193 (1928). Mason in New Zeal. Journ. Sci. 30: 384 (1960). Wild in Kirkia 2: 39, t. 13, d (1961). L. muscoides Harv. var. major Ridley in J. Linn. Soc. Bot. 22: 233 (1886).* Syntypes: Cape, Victoria East, Umdizine River, Cooper 17 (K, PRE); Transvaal, Bronkhorstspruit, Rehmann 6559 (K); Bethal, Trigardtsfontein, Rehmann 6678 (K).

Elodea crispa hort. non Lagarosiphon crispus Rendle.

Stems about $3 \mathrm{~mm}$ in diam., usually firm. Leares alternate, laxly spaced below, dense above forming obtuse, troad apices, spreading-recurved, soft, usually fairly firm, opaque, linear, average size 16 by $2 \mathrm{~mm}$ (occasionally up to $3 \mathrm{~cm}$ ); apex obtuse to acute to accuminate, margin with the outermost row of cells hyaline, producing minute, blunt, closely-spaced teeth; leaf-tips with teeth similar to marginal; midrib sunk above, prominent below; lamina with small papillose, rhomboid cells when viewed from above, those of the midrib slightly longer and larger. Male inflorescence: spathe-valves oblong-lanceolate, 5 by $3 \mathrm{~mm}$, with about $8-9$ teeth on each side, bearing about 50 flowers consecutively, perianth pinkish. Female inflorescence: spathe-valves ovoid, up to 5.5 by $2.5 \mathrm{~mm}$, with about 12 teeth on one side and about 6 on the other; perianth pink, maximum length $15 \mathrm{~cm}$; ovary flask-shaped, stigmas red, ovules about 12. Capsule ovoid, about $5 \mathrm{~mm}$ long; seeds about $2 \mathrm{~mm}$ long.

Widespread in southern Africa from the eastern Cape, Orange Free State, Transvaal to Southern Rhodesia. Recorded as an adventive from Europe and New Zealand.

CAPE.-King William's Town: near King William's Town, Sim 1561.

NATAL. - Newcastle: W. of Laingsnek-Quaggasnek Rd., Ediards 2369.

Orange Free State.-Boshoff: Smitskraal, Burtt Davy in PRE 10731.

TransvaAl.-Piet Retief: Kleber 3 . Standerton: Schlechter 3464 . Belfast: Wager NH 49186 \%; Franks in PRE 9770. Pretoria: Rietvlei Dam, Repton 2001. Germiston: Birchleigh, Wager NH 49187 jै, ㅇ. Potchefstroom: Frederikstad, Louw 1709.

Southern RhOdesia.-Umitali, Tsungwesi River, Wild 4649. Salisbury, Hunyani Poort Dam, Wild 4146. Matobo: Matopos Dam, Rattray in SRGH 82664.

Usually sterile. Often an obnoxious water pest, choking pans in the Republic and Southern Rhodesia.

5. L. ilicifolius Oberm., sp. nov.

Planta robusta. Caulis ca $3 \mathrm{~mm}$ diam. albidus. Folia alterna interdum subopposita lamine opaca reflexa lanceolata $8 \times 2.5 \mathrm{~mm}$ margine dentibus patentibus Ilici simili basi triangulari. Cellulae quadrangulare sparse papillosae. Spatharum valvae anguste ovatae dentatae; ovarium ovoideum attenuatum 9-ovulatis. Capsula ovoidea. Semen $2 \mathrm{~mm}$ longum.

Type: Bechuanaland, Bridge at Toteng on the N.E. tip of Lake Ngami, Story 4727 (PRE, holotype).

Stems about $3 \mathrm{~mm}$ in diam. (thinner in fertile plants), usually firm, whitish. Leaves alternate, occasionally subopposite, regularly spaced below with the internodes about 3-6 mm long, densely leafy above forming broad obtuse apices to the shoots, reflexed or recurved, fairly firm, opaque, lanceolate, average size 8 by $2.5 \mathrm{~mm}$ (smaller in fertile plants) apex acute, margin with the outer row of cells hyaline, with the patent strong teeth situated on broad triangular excrescences, closely spaced, leaf-tip with 2 teeth similar to marginal ones; all cells of the lamina small, similar, squared and somewhat papillose viewed from above, midrib faint depressed, prominent-below, purplish in dried specimens, its cells somewhat longer and narrower. Male inflorescence unknown. Female inflorescence: spathe-valves narrow-ovate, $4 \mathrm{~mm}$ long, toothed or

* F. C. 5, 3: 1 (1912). 
entire, acute, pale wine red; perianth pale lilac (Story); ovary ovoid, attenuate, ovules about 9, funicle erect, short. Capsule ovoid, tapered towards the apex, 5-7 $\mathrm{mm}$ long; seeds $2 \mathrm{~mm}$.

Recorded from Northern South West Africa (Okavango River), northern Bechuanaland (Lake Ngami), Southern and Northern Rhodesia (Zambesi River).

South WeST AfRICA.---Okavango Native Territory, lagoon in Okavango River at Kapako Camp, 4 miles W. of Mupini Mission, de Winter \& Marais 4516; Runtu, bog and riverbed of Okavango River, Mer.xmüller 1890; Niangana, Okavango River, Dinter 7202a.

Bechuanaland.-Bridge at Toteng on the N.E. tip of Iake Ngami, Story 4727 (PRE, holo.); McConnell in SRGH 68901; Maun, Thamalakane River, McConnell in SRGH 68903.

Southern Rhodesia.--Zambesi River just above Victoria Falls, Galpin 7027; Wilde in TRV 9066; Young 1592; Sim 19176; Wild 3111 (SRGH).

Northern Rhodesia.-Livingstone, Zambesi River, Greenway 6252. Mangu, Luanginga River, about 4 miles N.W. of Sandaula Pontoon, Drummond \& Cookson 6586.

Usually sterile in which case it is much coarser than the female plants collected at lake Ngami.

NotE.--The tropical African types of L. schweinfurthii Casp., L. steudneri Casp., L. cordofanus Casp. and L. fischeri Gürke were not found at Berlin: probably destroyed in 1943.

\section{ACKNOWLEDGMENTS}

For loan of material I sincerely thank the Keepers of the Southern Rhodesian Herbarium, Salisbury, the Bolus Herbarium, Cape Town, the Natal Herbarium, Durban and that of the Eastern Province at the Albany Museum. From Dr. M. ErnstSchwarzenbach we gratefully received reprints of her work on this genus. L ast but not least my sincere thanks to Mr. J. E. Dandy, Keeper of Botany, British Museum (Natural History) for his helpful comments. 